\title{
RARE FEATURES IN A CASE OF GAUCHER'S DISEASE
}

\author{
BY \\ E. ADLER and S. MAYBAUM \\ From the Department for Physical Medicine and Rehabilitation, Hadassah University Hospital, \\ and Hebrew University Hadassah Medical School, Jerusalem
}

(RECEIVED FOR PUBLICATION MAY 3, 1954)

Descriptions of the osseous lesions in Gaucher's disease have been published from the clinical, radiological, and pathological point of view. The most common sites of these lesions are the hip-joint (e.g., Brill and others, 1905; Todd and Keidan, 1952; Vaughan-Jackson, 1952; Wood, 1952), the mandibular joint (Cecil, 1948; Snapper, 1943), and the knees (Draznin and Singer, 1948; James, 1952; Kroboth and Johnson, 1952; Markovits, 1949; Pick, 1927), including the lower part of the shaft of the femur with its typical flask-like deformity (Davies, 1952; Windholz and Foster, 1948). Affections of the shoulder bones seem to be less frequent; Pick (1927), reviewing the literature as a pathologist and adding four cases of his own, does not mention involvement of the upper extremity except in the case described by Brill and others (1905). Apart from these, we have found only four cases with lesions at this site in the literature available to us (James, 1952; Kroboth and Johnson, 1952; Morgans, 1947; Snapper, 1943). Pre-existing osseous affections are prone to deterioration after splenectomy according to Snapper (1943), but the development of new osseous lesions after this operation has been described only rarely (Meakins, 1950; Todd and Keidan, 1952; Vaughan-Jackson, 1952), and then usually a few months to 2 years after removal of the spleen (Windholz and Foster, 1948; Wood, 1952).

Finally, to the best of our knowledge, the almost simultaneous appearance of clinical manifestations of rheumatic fever and bone lesions due to Gaucher's disease have not been recorded.

Our case showed, in addition to the rare features indicated above, a relatively good response to simple physical treatment, and it was therefore thought worth while to report it.

\section{Case Report}

A 31-year-old baker, of German-Jewish origin (No. 144608/1953), married and with two healthy children, migrated to Palestine in 1933 at the age of 21 . His family history was irrelevant.

Previous Medical History.-At the age of 3 years an enlarged spleen was found and the tentative diagnosis of Gaucher's disease was made.

In December, 1937, when he was 25 years old, a splenectomy had been performed in another hospital in Palestine; the pathological report described a very large spleen and the clinical diagnosis was confirmed by histological examination. Before operation the number of thrombocytes was 40,000 per c.mm.; after the operation this increased to $1,170,000$, and normal levels returned within a few weeks. The post-operative course was uneventful and the patient felt well for the next 10 years.

In 1947 he contracted infective hepatitis, was hospitalized, and returned to work after 6 weeks.

In August, 1951, he fell ill with a typical rheumatic fever and was treated in the Haifa Government Hospital; slight cardiac involvement developed at this time, but he reacted well to salicylate treatment, and when discharged on October 3, 1951, was in good general condition, but still showing a rather high blood sedimentation rate $(60 \mathrm{~mm}$. $/ \mathrm{hr}$ (Westergren)). At this time $x$-ray examination of the bones (including the humerus), showed no abnormalities, but a bone-marrow puncture revealed many typical Gaucher cells.

Six months later, the patient developed a swollen right ankle after having slipped in the street, and shortly afterwards a slight swelling of the left ankle interfering with locomotion. In addition, severe pain was felt in both knees, accompanied by restriction of movement. Several orthopaedic surgeons advised him to have the menisci removed, but the patient refused surgery. He was given short-wave diathermy and ultrasonic therapy with only doubtful improvement. During the course of this treatment, in July, 1952, severe pain was felt in the right shoulder, and an $x$ ray revealed destructive changes in the head of the right humerus. He received treatment with ACTH and cortisone, which afforded only slight relief for a very short period.

In May, 1953, his tonsils were removed, and treatment with autovaccine was given, without satisfactory results.

In August, 1953, the patient was seen in our Out- 


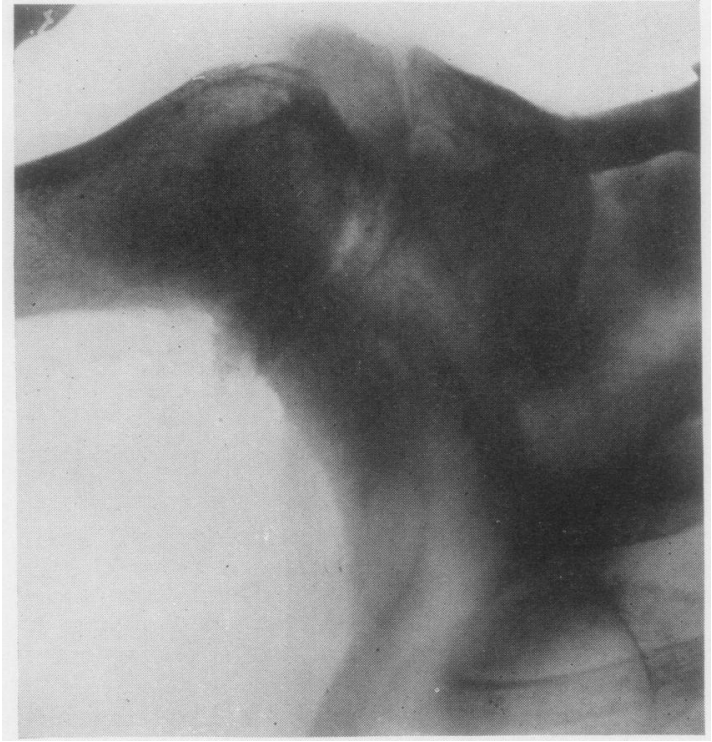

Fig. 1.-Radiograph of shoulder, showing partial destruction of proximal end of humeral head.

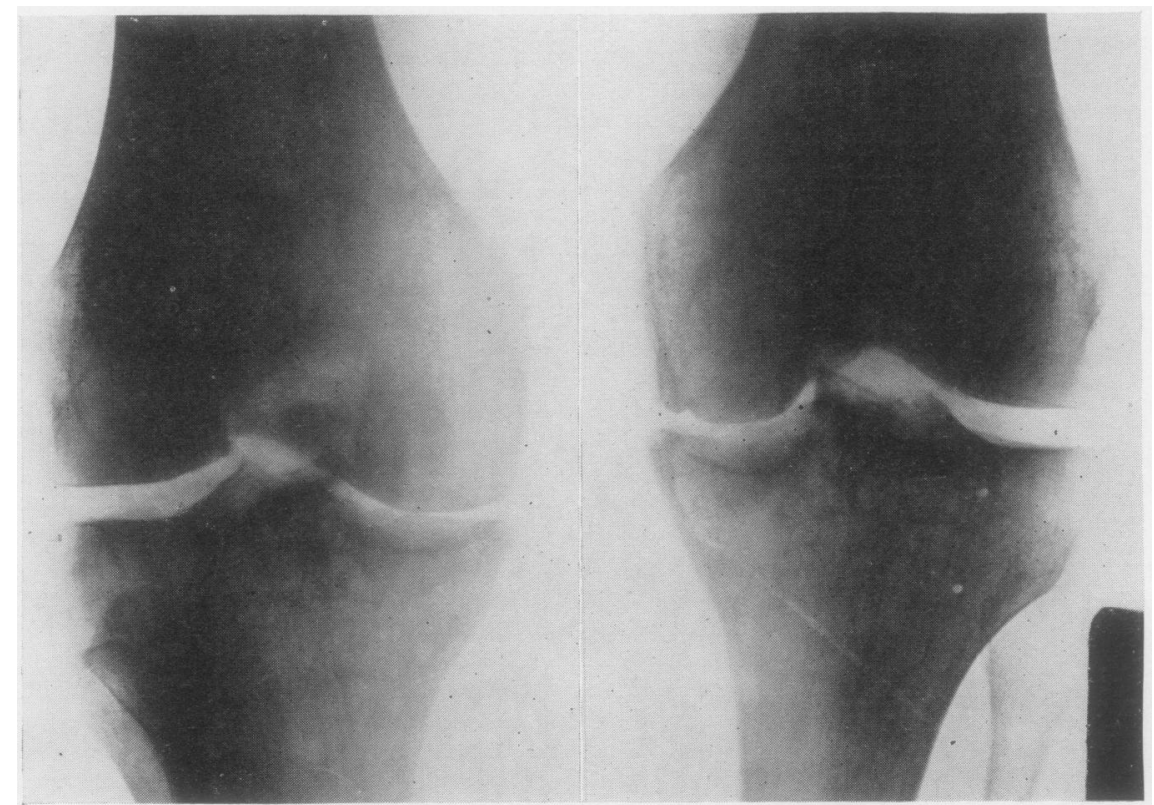

Fig. 3.-Radiographs of knees, antero-posterior view.
Fig. 2.-Radiograph elbow, lateral view.

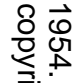

pingueculae of bot sclerae, marked hypometropia, and bi- $\frac{\bar{O}}{\mathrm{O}}$ lateral exophthalmos; a movable firm gland of cherry size was palpated in the right axilla; the thyroid was not enlarged. In the heart the first sound at the apex was prolonged and muffled, $P_{2}$ accentuated, blood pressure $120 / 80 \mathrm{~mm}$. $\mathrm{Hg}$. The liver was smooth and palpable $4 \mathrm{~cm}$. below the costal arch. There were no other internal or neurological abnormalities.

Joints.-The right shoulder had almost

Patient Department, having been unable to work for the last 4 months.

General Examination.-He appeared ill-nourished; his face was greyish-yellow and spotted with brown pigment which was also present on the arms and legs; there were no movement and severe atrophy of all shoulder muscles was found.

The left elbow had extension of $160^{\circ}$ only, very slightly restricted flexion, painful on movement.

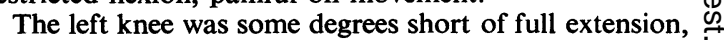
and slightly tender on movement. 
The other joints (including the hips and mandibular joints) showed no abnormality.

Laboratory Findings:

Albumin: traces.

Blood sedimentation rate: $8 \mathrm{~mm}$./hr (Westergren). Blood count: erythrocytes 3,700,000; haemoglobin 12 g. per cent.; leucocytes $14,000 / \mathrm{c} . \mathrm{mm}$.; thrombocytes 122,000 ; coagulation time $3 \mathrm{~min}$.; bleeding time $1 \mathrm{~min}$.; neutrophils 48 per cent., lymphocytes 42 per cent., eosinophils 6 per cent., monocytes 4 per cent. (target cells?).

Blood chemistry: cholesterol $250 \mathrm{mg}$. per cent., prothrombin time 61 per cent., phosphor $3.3 \mathrm{mg}$. per cent., thymol turbidity test $2-3$, cephaline 0 , Takata Ara 0.

$X$-ray Findings:

Heart: Slight dilatation of left ventricle; questionable configuration of mitral heart.

Lung fields: Not abnormal.

Joints: Right shoulder: condensed areas with partial destruction of proximal end of humeral head, articular surface being hazy. No change in glenoid fossa (Fig. 1).

Left elbow: head of radius dislocated in frontal direction at epiphyseal line; anterior articular space narrowed (Fig. 2).

Lumbar spine: spotty condensation of $\mathbf{L 4}$, its upper border not sharply defined; L3 intervertebral space narrowed (anteriorposterior and lateral view).

Sacro-iliac joints: border of left joint not sharp, showing small cystic defects, particularly in lower parts.

Femora: no dilatation of distal shaft visible on either side.

Knee joints: sharpening and prominence of eminentia intercondyloidea in both knees, some unevenness of articular surface of both tibiae, particularly medially and anteriorly (Fig. 3).

No other joints showed abnormalities.

Treatment was undertaken cautiously. Peri-articular novocaine infiltration was given to the shoulders and knees, and heat application and progressive remedial exercises were begun. To our surprise, 3 weeks after having started therapy, the patient was able to raise his right arm to $90^{\circ}$ in forward flexion, and to $45^{\circ}$ in abduction. Even rotation was possible to more than $20^{\prime \prime}$. The right knee could be almost fully extended. His pains disappeared almost entirely; he walked freely for more than half an hour at a stretch, and he was able to use his right arm to a considerable extent. He was advised to return to work and to continue the exercises at home, and 4 months after discharge his movements showed no deterioration. He has resumed work in his profession at full capacity.

\section{Discussion}

This case showed some unusual features:

(a) The disease affected the humeral-acromial joint and caused complete incapacity.

(b) The involvement of the bones occurred 17 years after splenectomy, a sequel which has not been reported until now. (c) Rheumatic fever occurred almost simultaneously with the appearance of symptoms in the shoulder which were due to Gaucher's disease. It could not be determined whether the rheumatic fever predisposed to the development of bony Gaucher's disease, promoting it as a kind of trigger mechanism, or whether it was a coincidental event.

(d) Degenerative osteo-arthritic changes were also encountered in some joints at the same time.

The patient was treated in the same way as any other "frozen shoulder" in our department by heat, novocain infiltration, and simple exercises, and he was able to return to work after a short course of this therapy (Adler, 1948; Adler and Grossmann, 1946).

\section{Summary}

(1) The literature on Gaucher's disease affecting the osseous system is surveyed briefly.

(2) A case is presented in which clinical bone manifestations and degenerative osteo-arthritis began after a bout of rheumatic fever which occurred 17 years after splenectomy.

(3) Several unusual aspects of this case are stressed: the rare involvement of the shoulder joint; the development of osseous lesions many years after splenectomy; the simultaneous appearance of rheumatic fever and bony manifestations of Gaucher's disease.

(4) The response to physical treatment and the possibility of rehabilitation are emphasized.

\section{REFERENCES}

Adler, E. (1948). Harefuah, 34, 133.

-, and Grossmann, C. (1946). Acta med. orient., 5, 33.

Brill, N. E., Mandlebaum, F. S., and Libman, E. (1905). Amer. J. med. Sci., 129, 491 .

Cecil, R. L. (1948). "Textbook of Medicine", 7th ed., p. 1177 Saunders, Philadelphia.

Davies, F. W. T. (1952). J. Bone Jt Surg., 34B, 454.

Draznin, S. Z., and Singer, K. (1948). Amer. J. Roentgenol., 60, 490 James, N. E. (1952). J. Bone Jt Surg., 34B, 464.

Kroboth, F. J., Jr., and Johnson, E. W., Jr. (1952). S. Clin. N. Amer., 32, i141.

Meakins, J. C. (1950). "The Practice of Medicine", 5th ed., p. 576. Mosby, St. Louis.

Markovits, E. (1949). "Bone and Joint Radiology". MacMillan, New York.

Morgans, M. E. (1947). Lancet, 2, 576.

Pick, L. (1927). "Die Skelettform (ossuare form) des Morbus Gaucher", Veroff. Kriegs- u. KonstitPath., 4, no. 3 [Heft 17].

Snapper, I. (1943). "Medical Clinics on Bone Diseases", p. 174. Interscience, New York.

Todd, R. McL., and Keidan, S. E. (1952). J. Bone Jt Surg., 34B, 447. Vaughan-Jackson, O. J. (1952). Ibid., 34B, 460.

Windholz, F., and Foster, S. E. (1948). Amer. J. Roentgenol.,

Wood, H. L. C. (1952). J. Bone Jt Surg., 34B, 462.

AdDitional Bibliography Bloem, T. F., Groen, J., and Postma, C. (1936). Quart. J. Med.,

Copeman, W. S. C. (1948). "Textbook of the Rheumatic Diseases". Livingstone, Edinburgh.

Groen, J. (1948). Blood, 3, 1238.

, and Garrer, A. H. (1948). Ibid., 3, 1221.

Kveim, A. (1935). Norsk. Mag. Laegevidensk., 96, 696. Abs. in J. Amer. med. Ass., 105, 844. 
Pancoast, H. K., Pendergrass, E. P., and Schaeffer, J. P. (1940). "The Head and Neck in Roentgen Diagnosis", vol. 2. Thomas, Springfield, Ill.

Pillmore, G. U. (1950). “Clinical Radiology”. Davis, Philadelphia. Petit, J., V., and Schleicher, E. M. (1943). Amer. J. clin. Path., 13, 260 .

Wintrobe, M. M. (1950). In "Principles of Internal Medicine", ed. T. R. Harrison, p. 1223. Blakiston, Toronto and Philadelphia.

Rares traits d'un cas de maladie de Gaucher

RÉSUMÉ

(1) On passe brèvement en revue la littérature sur la maladie de Gaucher affectant le système osseux.

(2) On présente l'observation d'un cas où les manifestations osseuses et de dégénérescence ostéo-arthritique avaient débuté après une attaque de rhumatisme articulaire aigu, celui-ci survenant 17 ans après la splenectomie.

(3) On souligne plusieurs aspects rares de ce cas: implication rare de l'articulation de l'épaule; apparence des lésions osseuses bien des années après la splenectomie; apparence simultanée du rhumatisme articulaire aigu et des manifestations osseuses de la maladie de Gaucher.

(4) On met en relief la reponse à la physiothérapie et la possibilité de rehabilitation.

\section{Raros rasgos de un caso de enfermedad de Gaucher} SUMARIO

(1) Se pasa en revista la literatura sobre la enfermedad de Gaucher afectando el sistema óseo.

(2) Se presenta un caso en que las manifestaciones óseas y osteoartríticas degenerativas empezaron después de un ataque de reumatismo poliarticular agudo el cual ocurrió 17 años después de la esplenectomía.

(3) Se subraya varios aspectos raros de este caso: $\overrightarrow{0}$ implicación poco común de la articulación del hombro; desarrollo de las lesiones óseas muchos años después de la esplenectomía; aparición simultánea del reumatismo poliarticular agudo y de las manifestaciones óseas de la enfermedad de Gaucher.

(4) Se acentua la respuesta a la fisioterapia y la $\frac{\dot{\omega}}{\omega}$ posibilidad de rehabilitación. 